\title{
「東關図」にみられる朝鮮時代の宮殿造園における 構成要素の特徵
}

\author{
Characteristics of Landscape Architectural Elements in the Royal Palace of Joseon Dynasty on Donggweoldo
}

金 鉝 埈* 権 孝 姃 ${ }^{* *}$ 沈 愚 京* Hyunjun KIM Hyojung KWEON Wookyung SIM

\begin{abstract}
Donggweoldo is a painting which was drawn on royal palaces (Changdeok palace, Changgyung palace and Whowon) of Joseon dynasty. The situation of landscape design on 19 century could be grasped from Donggweoldo, because the painting was produced in the 1820s. The purpose of this study is to clarify the characteristics of landscape architectural elements in Korean royal places by analyzing Donggweoldo. To analyze landscape architectural elements and clarify characteristics of those, the elements were classified to spatial elements, house elements, plant elements, water elements, stone elements. The appearance frequency of those elements was different as a role of the place. It is understood that Confucianism was reflected by elements in the place such as Uezo where retainers work or Chizo where is held ceremonies. There are various ornamental elements in Yeonzo where a king and his family live and Whowon which is a large garden where people relax and enjoy nature. Especially in back yard of king's bed house, there are ornamental elements such as flower terrace, various plant, oddly shaped stone. These data is expected to be a fundamental data when royal places restored to original state.
\end{abstract}

Keywords: Donggweoldo, Joseon dynasty, royal palaces, landscape architectural elements キーワード : 「東關図」, 朝鮮時代, 宮殿, 造園構成要素

\section{1. 研究背景および目的}

「東關図」は朝鮮時代 $\left(1392-1910\right.$ 年) の正宮 ${ }^{1)}$ である景福宮 の東側に位置した昌徳宮と昌慶宮の建築物・樹木・施設物などを 細かく描写した作品で, 5 節 6 面 16 巻の画帖から構成されてい る。完全に開いた大きさが縦 $273 \mathrm{~cm} ・$ 横 $584 \mathrm{~cm}$ の大型の絵であ る ${ }^{2)}$ 。絵の内容から 1820 年代に描かれたとみられ, 現存する韓 国の宮殿の絵として規模・内容などのすべての面で, 屯っとも優 れた作品として評価されている。絵画・建築・造園における歴史的 な側面から大事な資料であり，さまざまな分野で研究されてきた。

昌徳宮は 1405 年に建てられ, 昌慶宮とともに, 正宮である景 福宮の東側にあることから東闒と呼ばれた。朝鮮時代の宮殿のな かでもっとも長い期間, 国王が住んでいた宮殿である。現存して いる宮殿のなかで，もっともよい状態で保存されている。自然の 地勢によって建物が配置され, 自然に順応する韓国造園の特徴が よく表現されている。1970 年代から整備がはじまり，1990 年代 以降, 重要な建物の復元作業が進められ, 正殿・寝殿・楽善斉・ 後苑地域などが復元された。自然と調和した建物の配置などが認 められ，1997 年 12 月ユネスコの世界文化遺産として登録された。 昌慶宮は 1483 年に建てられた宮殿であり, 昌徳宮と繋がり, 一 つの大規模な宮殿を形成している。

既往研究として,「東關図」の昌徳宮の造園構成要素の役割に ついて述べたものがあるが ${ }^{3)}$, 本研究では造園構成要素を「東闒 図」の全体から抽出し, その出現頻度などを整理することで, 各 要素の意味および役割を明らかにすることを試みた。

本研究は,「東關図」に見られる造園の構成要素の特徵を分析 し，「東關図」が描かれた 19 世紀の朝鮮時代の宮殿における造園 の特徴について調べるこで, 復元における基礎的資料となるこ とを目的とする。

\section{2. 研究方法}

本研究では, 韓国ソウル市の高麗大学博物館に所蔵されている
「東關図」を部分撮影した 24 枚の $4 \times 5$ inch フィルムを, 4,800dpi でスキャンし，そのイメージを利用した。分析のため, 昌徳宮, 昌慶宮, 後苑の 3 つに地域に分け, さらにその各地域を 昌徳宮 20 ヶ所，昌慶宮 22 ヶ所，後苑 14 ヶ所に分割した。造園 的な構成要素を空間・建築・樹木関連・水関連・石などの要素に 分類した。なお，既に研究されている樹木については除外した ${ }^{4)} 。$

\section{3. 地域区分}

分析のため,「東關図」は図－1のように地域区分を行った。 「東關図」における宮殿区画の内側を研究対象地とし, 建物と区 画構成, または空間利用の性格によって, 昌徳宮地域は $\mathrm{A} 1$ ～20, 昌慶宮地域は B1～22, 後苑地域は C1〜14 に分けられた（図-1)。 C14 の地域は中国明時代の皇帝の法事のためにつくられた皇壇が ある地域で，本来は後苑と壁で分離されているが，区分の便宜上， 後苑地域に含めた。

宮殿空間を臣下が勤務する官庁がある空間である外朝，正殿お よび便殿が位置し, 国王が政治を勤める場所である治朝, 国王・ 王妃など王族の生活空間である燕朝，そして後苑に分けた。昌徳 宮地域では A1, A3, A5, A8, A19, A20 が外朝, A2, A4, A6, A7, A9, A10 が治朝, A11, A12, A13, A14, A15, A16, A17,

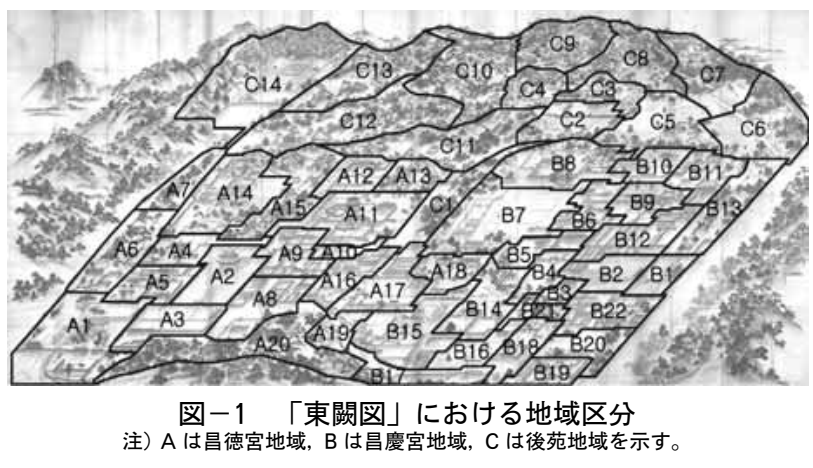

*(韓国) 高麗大学造景学研究室 **兵庫県立大学自然 - 環境科学研究所/淡路景観園芸学校 
$\mathrm{A} 18$ が燕朝に該当する。昌慶宮地域では $\mathrm{B} 1, \mathrm{~B} 12, \mathrm{~B} 13, \mathrm{~B} 15, \mathrm{~B}$ 17, B18，B19，B20，B22 が外朝，B2，B3，B4，が治朝，B5，B6, B7，B8，B9，B10，B11，B14，B16，B21 が燕朝である。

\section{4. 造園構成要素の特徵}

\section{(1) 空間要素}

(i ) 橋

昌徳宮には石橋が 6 ヶ所, 木橋が 1 ヶ所, 昌慶宮には石橋が 6 ヶ 所, 木橋が 1 ヶ所, 後苑には石橋が 25 ヶ所, 木橋が 4 ヶ所描かれて いた。橋のほとんどが石橋であることが分かった。昌徳宮と昌慶 宮では，木橋はすべてが各宮殿への進入空間にあった。宮殿への 進入空間における橋は, 川を渡ることが空間の変化において大事 な意味をもち, 王権を象徵したり, 俗世との境界などを象徵したり する ${ }^{5)}$ 。昌徳宮の錦川橋と昌慶宮の玉川橋がこのような意味をも ち，これらの石橋は各宮殿の正門から正殿までつながる「御道」 に位置している。「御道」は道の真ん中の高さが高くなり, 国王 だけが通れる道である ${ }^{6)}$ 。身分によって使う道が異なることを考 えると, 錦川橋の北側と玉川橋の南側（図－2）に設置されてい る木橋は，宮殿のなかで身分が低い人が利用した橋と思われる。
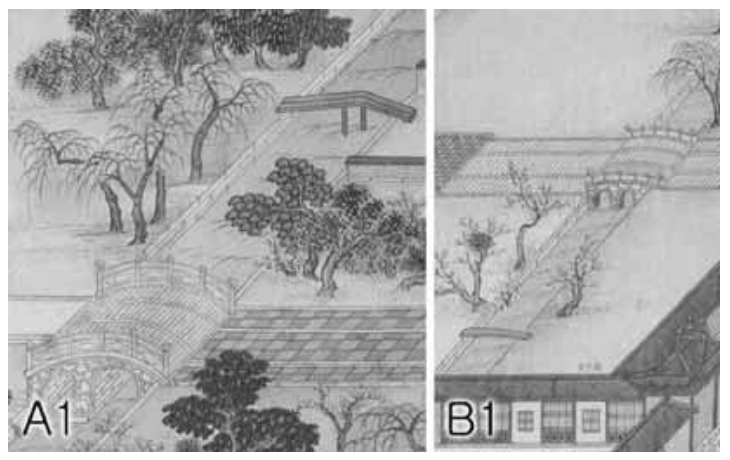

図－2「東闕図」における錦川橋・木橋（A1）および玉川橋・木橋（B1） (ii) 御道

御道は正殿の前や宗廟のような儀式が行われる空間につくられ ている。一般的には真ん中が高く, 両端が低い形態であり, 真ん 中の高い道を国王が通ったといわれる。「東關図」では, 御道が 各宮殿の正門から正殿まで, そして便殿, 寝殿, 大妃殿, 世子宮 （東宮）地域で見られた。これらの空間は, 重要な行事や儀式が 行われる空間であり，国王および王族の生活空間であることがわ かった。

\section{(iii) 板墻}

板墻は木の柱の間に板をつけて造られたもので7), 視線遮蔽の 効果および空間分割の機能をもっている。「東關図」では柱に木の 板をつけて移動が可能なように造られているものと, 地面に固定

表一1「東關図」に表れた花階の位置および特徵

\begin{tabular}{|c|c|c|c|c|}
\hline 区分 & 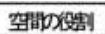 & 位 置 & 段数 & 特 徵 \\
\hline $\mathrm{A} 2$ & 治朝 & 伍政殿の北側 & 5 段 & 4-5段目にシササ類の盙栽 \\
\hline A9 & 治朝 & 宝慶堂, 泰和堂の北側 & 3 段 & 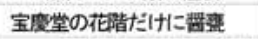 \\
\hline $\mathrm{A} 11$ & 燕朝 & 大造殿の北·東側 & 3段 & ッツジ䅡などの潅木䫅の植栽 \\
\hline $\mathrm{A} 14$ & 燕朝 & 景福熉跡地の北側 & 3段 & 植载なし，火災により焼失 \\
\hline B3 & 治朝 & 文政殿 & 2段 & 樌载なし \\
\hline B4 & 治朝 & 甞文堂の西側 & 3 段 & 植载なし \\
\hline B5 & 燕朝 & 景春殿の西側 & 3 段 & 花木類およひ潅木類の榑载 \\
\hline B7 & 燕朝 & 通明殿䟞地の西·北僋 & $\begin{array}{l}\text { 北2段 } \\
\text { 西3段 }\end{array}$ & 植栽なし火災によより焼失 \\
\hline B8 & 燕朝 & 意度殿の北側 & 2段 & 花木類およひ潅木類の植载 \\
\hline B14 & 燕朝 & 寿康斉の北側 & 3段 & マッ類 花木類 潅木類の媌载 \\
\hline B15 & 外朝 & 花国の北側 & 3 段 & 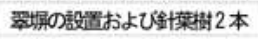 \\
\hline B16 & 燕朝 & 進修堂の北側 & 3段 & 花木類およひ潅木類の㨁裁 \\
\hline $\mathrm{C} 2$ & 後苑 & 宙合楼の南側 & 5 段 & 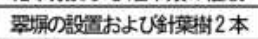 \\
\hline $\mathrm{C} 7$ & 後苑 & 钼德亭の北側 & 2段 & 植载なし \\
\hline $\mathrm{C} 14$ & 皇境 & 皇壇の北側 & 2段 & 2段目に多梾な栱木類 \\
\hline
\end{tabular}

されているものが確認できた。移動式のものは大きさが比較的小 さく, 主に視線遮蔽の目的で利用されることが多く, 固定式は壁 のような役割として空間の分割の目的での利用が多かったことと 思われる。板墻の色は赤色, 緑色, 白木色の 3 種類があり, 一般 的には赤色が使われた。王妃・大妃の生活空間には緑色がよくみ られ，宮殿で働く身分の低い人たちの空間では白木色が使われた。 既往研究 ${ }^{8)}$ によると, 赤色の板墻は東宮地域で公式的行事が行わ れる建物に，緑色のものは寝殿および亭子（あずまや）で使われ たと報告されているが，今回の分析結果からは，赤色の板墙は東 宮地域以外, 外朝, 燕朝で幅広くみられることがわかった。

（iv）花階

花階は，斜面のエロージョンを防ぐために細長い石を階段状に 積み, 複数の平地で作られた構造物である。花木類・怪石・石蓮 池などが設置され，美しい景観がつくられるので花階と呼ぶシ 。 比較的規模が小さい空間であるため, そこに植える植物は潅木お よび草花などであったが，空間に余裕がある場合にはマツ，モミ ジなども植えられた ${ }^{10}$ 。「東闕図」にみられる花階は昌徳宮地域 で 4 ヶ所, 昌慶宮地域で 8 ヶ所, 後苑地域で 3 ヶ所, 計 15 ヶ所 がみられる。その位置および特徵は表－1に示した。

花階は地形に沿って建物を建てる時に造られ，宮殿空間の性格 によって政治が行われた外朝および治朝にはほとんど設けられず, あるとしても地味な潅木類が植栽されている ${ }^{4)}$ 。しかし, 燕朝に は，花階に多様な広葉樹が植栽され，装飾的効果が望まれていた と考えられる（図－3）。なお，花園空間（B15）は昌慶宮の外 朝に属する場所にあったが, 用途は植物の植栽することによって 装飾的な空間をつくることにあったと推定される。

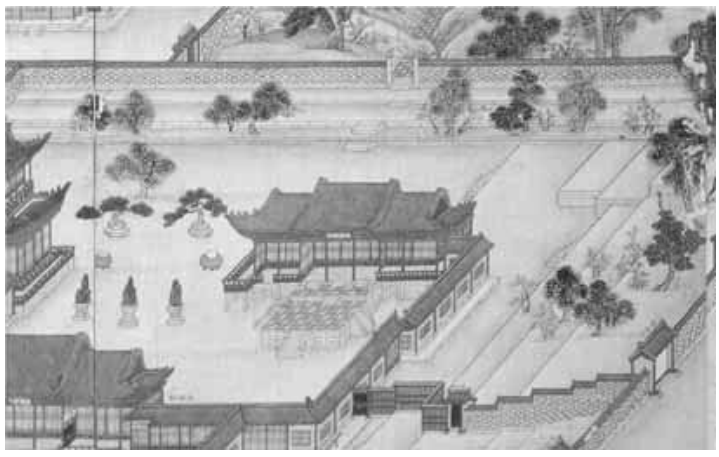

図－３「東關図」における大造殿の花階（A11）

\section{(2) 建築要素}

(i) 亭子

亭子は，休㮩をとったり，周囲の景観を観賞できたりする小さ な規模の建築物である。昌徳宮では亭子 2 ヶ所, 亭子の跡地 1 ヶ 所がみられた。昌慶宮には 4 ヶ所，後苑には 16 ヶ所あった。ほ とんどの亭子は後苑にあることがわかった。

(ii) 煙突

煙突は，暖房をとるため木を燃やすときに煙を外に出す建築物

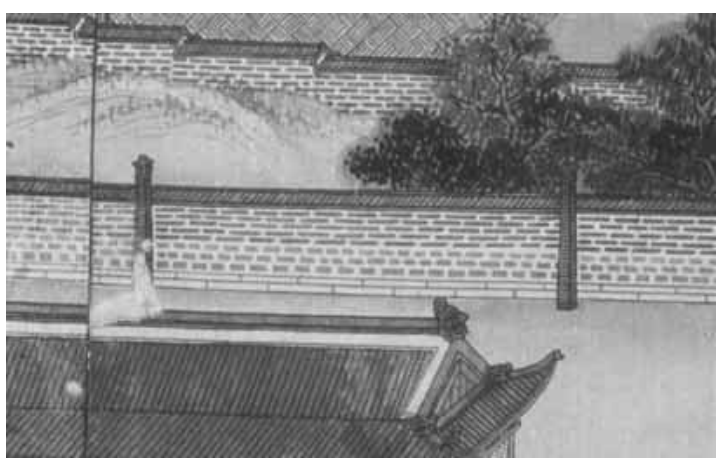

図－4「東關図」における煙突（A18） 


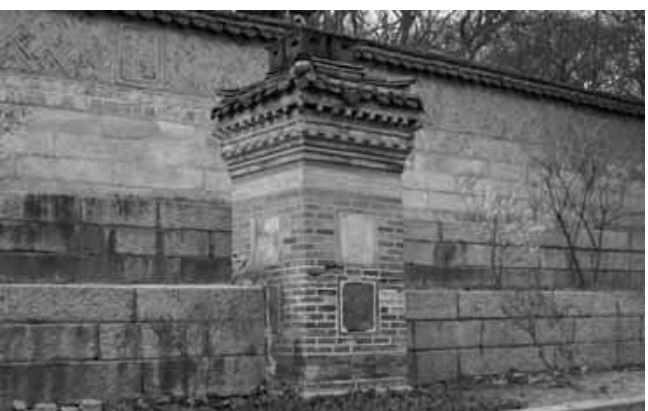

図- 5 現在の大造殿の花階の煙突 (A11)

の一部であるが, 韓国の伝統造園では, 煙突が建物からある程度 の距離を離れて設置され, 装飾的な要素として使われる場合があ る。昌徳宮では単純な形の煙突が 4 本みられるが (図一 -4 ), 昌 慶宮および後苑では見られない。現在は昌徳宮の大造殿の花階に 煙突が設置されているが (図一 5 ), 「東關図」には描かれていな い。

\section{(3) 樹木関連要素}

(i ) 翠屏

翠屏は生きている樹木に手をいれて造った生垣的な壁だが，現 存するものはない。「東閶図」には計 10 ヶ所の翠屏がみられ，そ の形態および特徴は表一2 に示した。

表一２「東關図」に表れた翠屏の位置および特徵

\begin{tabular}{|c|c|c|c|c|}
\hline 区分 & 空間历狆割 & 位 置 & 形態 & 役割および特徵 \\
\hline \multirow{3}{*}{ A17 } & \multirow{3}{*}{ 燕朝 } & 重熙堂の前 & L字 & 視線遮蔽 \\
\hline & & 重熙堂の前 & 直線 & 視線遮蔽 \\
\hline & & 小宙合楼の前 & 直線 & 空間分割およひ遮蔽。 台の上こ設置 \\
\hline B14 & 燕朝 & 翠雲亭の西側 & 直線 & 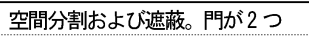 \\
\hline \multirow{2}{*}{ B15 } & \multirow{2}{*}{ 外朝 } & 花園の北側 & 直線 & 視線遮蔽 \\
\hline & & 花園の南西側 & L字 & 視線遮蔽 \\
\hline B16 & 燕朝 & 時敏堂跡地の南 & 直線 & 植栽なし，火災にによって焼失 \\
\hline \multirow{2}{*}{$\mathrm{C} 2$} & \multirow{2}{*}{ 後苑 } & 宙合楼の南側 & 直線 & 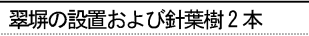 \\
\hline & & 喜雨楼の北側 & 直線 & 空間分割およひひ遮蔽。門が $1 つ$ \\
\hline $\mathrm{cg}$ & 後苑 & 南側 & 于型 & \\
\hline
\end{tabular}

翠屏は燕朝および後苑空間に設置されたもので，形態は直線型， $\mathrm{L}$ 字型, アーチ型の 3 つがある。花階に長く設置される場合, 翠 屏の機能的特性として, 視線遮蔽および空間分割機能をあげられ る。素材が植物であったことから, 観賞価值があり, 周辺の環境 とも調和しやすかったと考えられる。「東關図」によると, 宙合 楼の前面の花階に翠屏が設置されているが (図一), 現在は多様 な潅木が植栽されている。

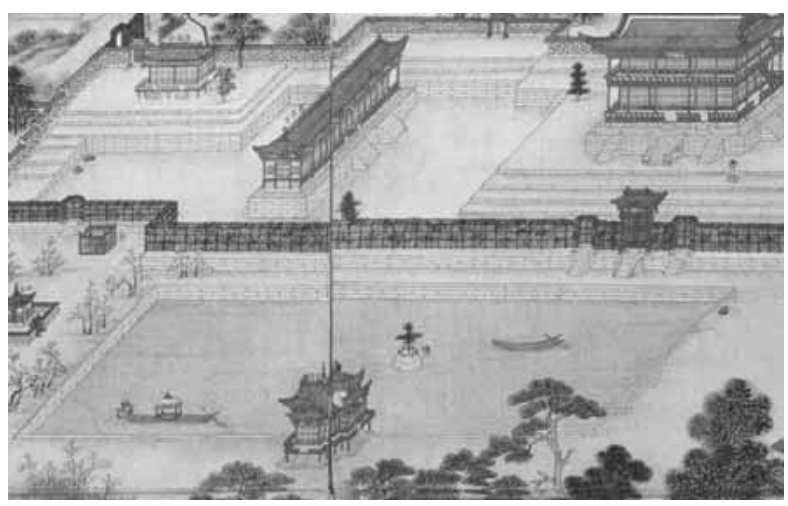

図－6 宙合楼の花階の翠屏および芙蓉池（C2）

(ii) 花盆

昌徳宮の燕朝空間には, マツの盆栽を植えた石鉢が 2 個, 花木 を植えた植木鉢が 7 個ある。後苑には守直間に花木が植えられた 鉢 4 個がみられる。このことから当時は, 宮殿のなかで花木を植 木鉢に植えて利用したことがわかる。 (iii）樹木の支柱

昌徳宮の輍源殿の前のイブキに 4 本，小西斉のとなりのイブキ に 6 本（図- 7 ), 景福殿のイブキに 10 本の支柱が設置されてい た。すべてがイブキに設置されている。現存する図ー 8 のイブキ は,「東䦕図」と同じ位置にあり, 樹齢が 700 年以上であること から，同じ樹木として見なされている。

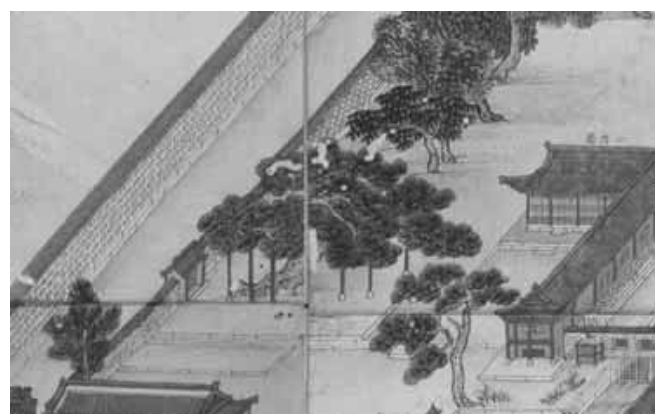

図－７「東闕図」における小酉斉のイブキと支柱（A6）

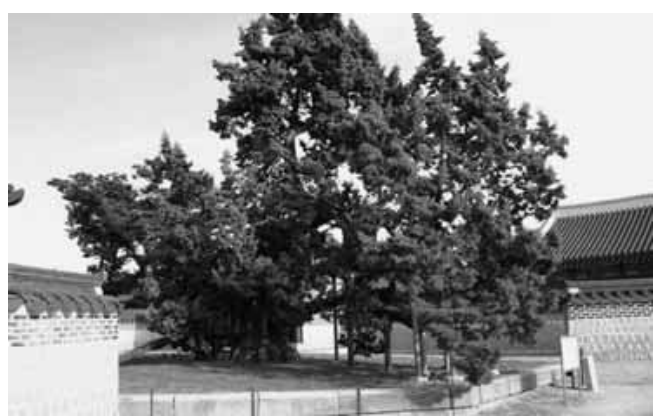

図ー8＼cjkstart現在の小酉斉のイブキと支柱 $(\mathrm{A} 6)$

\section{(4) 水関連要素}

(i) 池

「東閶図」における池は，ほとんどが方池の形をしている（図一 6 )。池の中に中島を造る場合があるが，これには三神山を描写 した神仙思想の影響がみられる。また，方池円島は天円地方と陰 陽の結合を象徴している ${ }^{11}$ 。昌徳宮に 2 ヶ所, 昌慶宮に 6 ヶ所, 後苑に 28 ヶ所, 計 37 ヶ所の池が主に燕朝と後苑空間にあった。 池の形別に分類すると, 方池が 35 ヶ所, 円池が 1 ヶ所, 半円池 が 1 ヶ所であり，池の中に円島があるところが 3 ヶ所，怪石があ るところが 3 ヶ所であった。これもまた天円地方・陰陽五行およ び神仙思想の影響であると考えられる。

(ii ) 井戸

井戸は, 昌徳宮に 8 ヶ所, 昌慶宮に 22 ヶ所, 後苑に 3 ヶ所, 計 33 ヶ所があった。四角形の井戸 3 ヶ所以外には，すべてが円 形であった。井戸は日常生活に必要な水を供給する場所であるた め, 宮殿全体に分布している。国王が使用するところは, 特別に 「御井」と呼ばれたが吕, 景薰閣, 寿命斉, 宙合楼, 皇壇の井戸 は他の場所と異なって欄干が設置されているところから，「御井」 であったと思われる。

(iii）玉流川

玉流川は自然の地勢を利用した韓国庭園の特色が，よく表れて いる場所である（図一-9）。この地域は現在もよく保存されている。 玉流川は岩で造られている場所であるため, 他の素材より火災な どの被害が少なかったと考えられる。

(5) 石要素

(i ) 怪石および石函

鑑賞を目的に庭園におかれた自然石を怪石といい，主に花階， 花壇，壁や樹木の下におく。石函は怪石を立たせるための台石の 一種で，怪石の台になるところから怪石台とも呼ばれる。怪石を おく場合には石函を使う場合（図一-3）上，石函なしで直接地面 


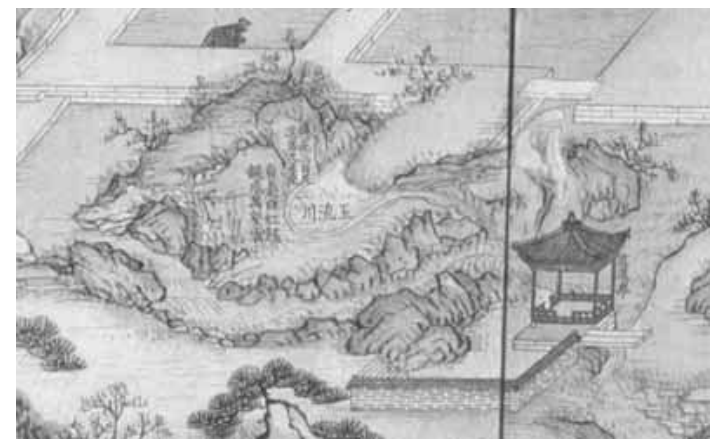

図一 9 「東關図」における玉流川（C6）

に下部を埋めておく場合があった。石函を使う場合には，一般的 に石函の三神山を象徴する文章を彫刻したり, 装飾をしたりした が，これは神仙思想の影響であるといわれる ${ }^{13}$ 。「東關図」では, 怪石は昌徳宮に 13 個, 昌慶宮に 1 個, 後苑に 7 個で, 計 21 個が 描かれ，そのなかで 16 個が石函の上に置かれていた。昌慶宮に 屯燕朝空間に 1 ヶ所の怪石が, 方池のなかにあった。怪石は目的 が鑑賞であったため, 空間の性格上, 外朝・治朝空間には設置さ れず, 燕朝・後苑の石函の上に設置されたり, 方池のなかに石函 なしで設置されたりしていたことがわかった。

(ii) 台石

台石は明かりや草花, 石函, 日時計などをおく台になるもので, 方形, 多角形, 円形などさまざまな形態をしている ${ }^{14)}$ 。昌德宮で は 19 個, 昌慶宮では 8 個, 後苑では 6 個, 計 23 個があり, 主に 燕朝空間で見られる。台石の用度が他のものをおくためのもので あるため，さまざまの構成要素が現れる燕朝空間でもっともよく 見られたと思われる。

\section{(iii) 石獣}

石獣は動物を彫刻しておいたもので，象徵的な意味と装飾的な 効果をもっている。昌徳宮と昌慶宮では各 6 個, 後苑では 5 個が 描かれている。昌徳宮の錦川橋と昌慶宮の玉川橋に設置された石 獣を除ければ，すべてが燕朝と後苑空間でみられた。

(iv) 下馬石

馬や駕籠を乗り降りする時に使用する石台である。本来の機能 以外に装飾的な効果もある。昌德宮には正門である敦化門の両側 に 2 つ, 昌慶宮に 1 つ, 後苑に 4 つが設置されていた。

(v) 灯籠

昌徳宮では石灯籠は 3 個, 石ではない灯籠は 12 個, 昌慶宮で は石灯籠は 6 個, 石ではない灯籠は 1 個, 後苑では石灯籠は 4 個, 石ではない灯籠は 1 個が見られた。灯籠はほとんどが燕朝と後苑 にあった。

(vi）品階石

品階石は宮殿の正殿の前, 御道の両側に「品階」を書いた石で ある。「品階」とは官職の階級である。「東關図」では昌徳宮の正 殿である仁政殿の前だけにあり, 左右 10 個ずつ, 計 20 個があっ た。朝鮮王族実録の正祖 1 年（1777） 4 巻に「立品右于仁政殿庭。 朝賀班次, 毎致紊乱, 命随品立標, 以定班行」という記録がある ところから，朝賀の時の乱れた雲囲気を正し，列をきれいにする ためのものであることがわかる。

\section{(6) その他}

昌徳宮・昌慶宮・後苑には, 測雨器・小簡儀・日時計・風旗な どの科学機器が設置されていた。「東關図」には, 科学機器とし て日時計がもっとも多く6つで, 測雨器が 3 つ, 風旗石が $3 つ$, 小簡儀が 4 つ, 計 14 の科学機器があった。外朝, 治朝, 燕朝空 間で現れ, 特に東宮である重熙堂に多く設置されている。重熙堂 が皇太子の空間であったことを考えると, その教育において科学 が重要であったと推測できる ${ }^{15)}$ 。その他, 宮殿のなかにある薬屋
に臼，釜などが描かれ，火事を防ぐことを象徴するために大事な 建物のそばに防火水をいれておいた，金属でつくられた盇のよう なものである「ドム」, 味増などの食料を貯蔵する「滰甕」, 池で 使う船などがみられた。

\section{5.まとめ}

本研究は「東關図」に現れた造園の構成要素を分析することで, その特徵を明らかにし,「東關図」が描かれた 19 世紀初の朝鮮時 代の宮殿の造園の特徵について考察したものである。「東關図」 には空間・建築・樹木関連・水関連・石などさまざまな構成要素 が描かれていた。空間の性格によって, これらの要素の出現頻度 が異なった。臣下が仕事を勤める空間である外朝, 行事および政 治が行われる治朝では，上下秩序をたもつために国王と臣下が使 う空間が異なるなど，儒教的な思想が造園構成の要素に大きく反 映されていることがわかった。国王および王妃，皇太子などの王 族の生活空間である燕朝, 休䡯と自然を楽しむことができる後苑 には多様な造園構成要素が現れている。とくに，寝殿の裏には花 階が設置され，さまざまな植物を植栽し，その周辺に怪石などの 装飾的側面を大きくもっている要素が見られた。怪石および池の 形, 池に浮かぶ島の形などから, 道教の神仙思想および陰陽五行 思想の影響を受けていたことを推測できる。井戸，灯籠，奨隼な どの要素によって当時の生活状をみることもできた。昌徳宮地域 と昌慶宮地域は構成要素の特徵についてはほとんど同じであるが, 煙突・花盆・樹木の支柱・品階石・ドムのような一部の構成要素 が昌徳宮だけで見られるなど, 細かい相違点があった。昌徳宮お よび昌慶宮は復元事業がすでに進められているが，「東關図」が 描かれた当時のような姿を取り戻すために, 多くの努力が必要之 考えられる。現在まで，建築物などのスケールの大きいところを 中心に復元事業が行われてきた。これからは本研究で分析した造 園構成の要素にも目を向けて，ディテールな面においても気を使 いながら復元していく必要があるといえる。このような細やかな 部分を大切にするよって, 各要素がもっている象徵的な意味や機 能性を明確にすることが可能になると思われる。

\section{補注および引用文献}

1)「正宮」は，その王朝において中心となる宮殿である。本来，東關は 離宮として建てられた宮殿である。

2 ) 安輝䜭 (2002)：古宮殿図：ダイエン社, ソウル

3 ）白志星・藤井英二郎・仲隆裕・浅野二郎（1992）：韓国・昌徳宮にお ける庭園植栽について：造園雑誌 55 (5), 1-6

$4 ）$ 金鉉埈・沈愚京 (2007)：「東關図」に表れた植栽現況および特徵分 析：韓国伝統造園学会誌 $25(2), 141-154$

5 ）池鋔紧（1994）：朝鮮時代宮關の造景構成要素に関する研究：高麗大 学校修士論文

6 ）朱南哲（1997）：韓国建築意匠：一志社, ソウル

7 ) 柳ジェ七（1991）：朝鮮時代の宮關建築の壁に関する研究：建国大学 校修士論文

8 ）洪善基（1991）：朝鮮時代の宮關の空間構造に関する研究：ソウル大 学校修士論文

9 ) 尹国炳 (1986)：造景辞典：一潮閣, ソウル

10）季瑄（2006）：韓国伝統造景植栽：樹流山房仲心，ソウル

11）朴吉龍（1984）: 韓国庭園の構成要素に関する研究: 韓国庭苑学会誌 3 (1), 2-3

12）文化財庁 (2002)：昌徳宮, 宗廟, 苑图：文化財庁, ソウル

13）全仁順（1990）：朝鮮時代の宮苑の造園要素における宗教的・思想的 背景に関する研究：成均館大学校修士論文

14）朱南哲（1980）：韓国庭園の石物に関する研究：大韓建築学会誌 24 (2), 34-43

15）文化財庁（2005）：「東關図」を読む：文化財庁, ソウル 